\title{
Distinct cytokine patterns may regulate the severity of neonatal asphyxia-an observational study
}

\author{
Anna Bajnok ${ }^{1,2}$, László Berta², Csaba Orbán², Gábor Veres³,4, Dénes Zádori ${ }^{3}$, Hajnalka Barta², Ünőke Méder², \\ László Vécsei ${ }^{3,4}$, Tivadar Tulassay ${ }^{2,5}$, Miklós Szabó ${ }^{2,5}$ and Gergely Toldi ${ }^{1,2,6^{*}}$ (D)
}

\begin{abstract}
Background: Neuroinflammation and a systemic inflammatory reaction are important features of perinatal asphyxia. Neuroinflammation may have dual aspects being a hindrance, but also a significant help in the recovery of the CNS. We aimed to assess intracellular cytokine levels of T-lymphocytes and plasma cytokine levels in moderate and severe asphyxia in order to identify players of the inflammatory response that may influence patient outcome.

Methods: We analyzed the data of 28 term neonates requiring moderate systemic hypothermia in a single-center observational study. Blood samples were collected between 3 and 6 h of life, at 24 h, 72 h, 1 week, and 1 month of life. Neonates were divided into a moderate $(n=17)$ and a severe $(n=11)$ group based on neuroradiological and amplitudeintegrated EEG characteristics. Peripheral blood mononuclear cells were assessed with flow cytometry. Cytokine plasma levels were measured using Bioplex immunoassays. Components of the kynurenine pathway were assessed by highperformance liquid chromatography.

Results: The prevalence and extravasation of IL-1b + CD4 cells were higher in severe than in moderate asphyxia at $6 \mathrm{~h}$. Based on Receiver operator curve analysis, the assessment of the prevalence of CD4+ IL-1 $\beta+$ and CD4+ IL-1 $\beta+$ CD49d+ cells at $6 \mathrm{~h}$ appears to be able to predict the severity of the insult at an early stage in asphyxia. Intracellular levels of TNF-a in CD4 cells were increased at all time points compared to $6 \mathrm{~h}$ in both groups. At 1 month, intracellular levels of TNF-a were higher in the severe group. Plasma IL-6 levels were higher at 1 week in the severe group and decreased by 1 month in the moderate group. Intracellular levels of IL-6 peaked at $24 \mathrm{~h}$ in both groups. Intracellular TGF- $\beta$ levels were increased from $24 \mathrm{~h}$ onwards in the moderate group.

Conclusions: IL-1 $\beta$ and IL- 6 appear to play a key role in the early events of the inflammatory response, while TNF- $\alpha$ seems to be responsible for prolonged neuroinflammation, potentially contributing to a worse outcome. The assessment of the prevalence of CD4+ IL-1 $\beta+$ and CD4+ IL-1 $\beta+C D 49 d+$ cells at $6 \mathrm{~h}$ appears to be able to predict the severity of the insult at an early stage in asphyxia.
\end{abstract}

Keywords: Perinatal asphyxia, Hypoxic ischemic encephalopathy, Neuroinflammation, Cytokine network

\footnotetext{
* Correspondence: toldigergely@yahoo.com

${ }^{1}$ First Department of Obstetrics and Gynecology, Semmelweis University,

Baross str. 27, Budapest $\mathrm{H}-1088$, Hungary

${ }^{2}$ First Department of Pediatrics, Semmelweis University, Bókay János str. 53-

54, Budapest $\mathrm{H}-1083$, Hungary

Full list of author information is available at the end of the article
} 


\section{Background}

Neonatal asphyxia evokes the injury of the central nervous system (CNS) due to the severe lack of oxygen and perfusion during labor and delivery, resulting in moderate to severe neurological dysfunction. Asphyxia primarily affects term and post-term neonates. It occurs in 2-4 of every 1000 live-born term neonates and is responsible for approximately $23 \%$ of neonatal deaths worldwide [1]. While some surviving children show favorable neurological outcome, others sustain severe neurodevelopmental disabilities such as mental retardation, sensory impairment, cerebral palsy, and seizures [2]. Identifying the factors responsible for such extent of individual variability regarding outcome would be critical; however, to date, no definitive predictive factors have been validated.

Inflammation of the CNS, or neuroinflammation, is now recognized to be a feature of all neurological disorders, including that related to neonatal asphyxia. Microglia and astrocytes become activated and release proinflammatory cytokines and chemokines. Disruption of the blood-brain barrier allows infiltration of peripheral monocytes into the brain that further enhances the inflammatory response, leading to neuronal injury and apoptosis. However, the inflammatory reaction following asphyxia is not limited to the CNS, but can also be detected in the periphery. Systemic immune activation is characterized by increased synthesis of proinflammatory cytokines [3]. A key player in the mediation of the inflammatory response both in the brain and peripheral blood during asphyxia is the subset of $\mathrm{T}$ lymphocytes. $\mathrm{T}$ lymphocytes have a pivotal role in the evolution of hypoxic injury. The mechanisms by which $\mathrm{T}$ cells are neurotoxic include the production of perforin and granzyme B, the release of free radicals, the triggering of apoptotic pathways within neurons, and most importantly, the production of pro- and anti-inflammatory cytokines $[4,5]$.

An extensive dataset describes neuroinflammation to have detrimental consequences, but results have indicated over the past decade that some aspects of the inflammatory response are beneficial for the CNS outcomes [6, 7]. Benefits of neuroinflammation include neuroprotection, the mobilization of neural precursors for repair, remyelination, and axonal regeneration. In vitro studies demonstrated that pro-inflammatory cytokines, such as TNF- $\alpha$ and IFN- $\gamma$, are toxic for oligodendrocytes [8-10]. Although inflammatory cytokines contribute to injury progression, they also play a vital role in the fast elimination of cellular debris, and in the processes of growth and repair, contributing to functional recovery $[11,12]$. The results of Saliba et al. support the positive role of certain cytokines in neuronal regeneration [13]. In addition to its toxic effect, TNF- $\alpha$ also plays a role in neuronal progenitor cell proliferation, lineage commitment, and cellular differentiation. IL-1 also has neurotrophic properties which might be mediated by the stimulation of nerve growth factor production. Direct intracerebral injection of IL-1 or TNF- $\alpha$ has been shown to stimulate astrogliosis and angiogenesis in the developing rodent brain [14]. The TGF- $\beta$ family consists of pleiotropic proteins with potent immunoregulatory properties, which might also play key roles in the development, repair, and survival of neurons [13].

Previous investigations in asphyxia demonstrated that pro-inflammatory IL- $1 \beta$, TNF- $\alpha$, and IFN- $\gamma$ play an outstanding role in the pathophysiology. IL-6, IL-8, and IL-17 (Th17 cells) also have an important contribution $[13,15-17]$. On the other hand, anti-inflammatory TGF- $\beta$ and IL-10 have a protective role and are important for regenerative processes [18]. Prolonged moderate hypothermia improves neurological outcome and has become standard care for term infants with hypoxicischemic encephalopathy over the recent years [19]. One mechanism by which hypothermia exerts a neuroprotective effect may be by reducing systemic inflammation [20]. In an earlier study, we measured cytokine levels at the 6th, 12th, and 24th postnatal hours in neonates with asphyxia treated with hypothermia or standard intensive care on normothermia [21]. Our results indicated that IL-6 levels (at $6 \mathrm{~h}$ of age) and IL-4 levels (at all time points) were significantly lower in asphyxiated neonates treated with hypothermia compared to normothermic neonates. The duration of hypothermia initiated before $6 \mathrm{~h}$ of age correlated with lower levels of IL-6, TNF- $\alpha$, and IFN- $\gamma$ measured at $6 \mathrm{~h}$ of age. These data suggest that therapeutic hypothermia may rapidly suppress and modify the immediate cytokine response in asphyxia.

The permeability of the $\mathrm{BBB}$ is higher in neonates compared to adults and is further disrupted by the hypoxic injury itself. The release of IL- $1 \beta$, TNF- $\alpha$, and IFN- $\gamma$ also increase the permeability of the $\mathrm{BBB}[22,23]$. CD49d is part of the VLA-4 antigen which mediates the migration of activated leukocytes to the site of tissue inflammation via binding to VCAM-1, expressed by endothelial cells [24]. VLA-4 is thus crucial for the migration of activated $\mathrm{T}$ lymphocytes through the $\mathrm{BBB}$ to the site of inflammation in the brain $[25,26]$, making it a primary therapeutic target in multiple sclerosis [27] and in primary neuroinflammatory brain disease in murine ischemic stroke models [28]. Although VCAM-1 is not exclusively expressed in the CNS, the level of CD49d expression can be correlated with the capacity of $\mathrm{T}$ lymphocytes to enter the site of inflammation, more specifically the brain tissue in the case of neuroinflammation [29].

The interplay between the kynurenine system and cytokines is a regulator of both innate and adaptive immune responses, and it plays an important role in the 
interactions between the central nervous and the immune systems [30, 31]. Indoleamine 2,3-dioxygenase (IDO), the rate-limiting enzyme in the degradation of tryptophan, plays a central role in regulating these interactions. IDO degrades TRP to kynurenine (KYN), which is then metabolized by the enzymes within the kynurenine pathway into other catabolites, such as Kynurenic acid (KYNA). While some TRP metabolites may have neurotoxic potential, KYNA appears to be a potent neuroprotective agent as it ameliorates NMDA receptormediated excitotoxicity [32] and acts as a potent free radical scavenger and endogenous antioxidant [33]. Induced by pro-inflammatory stimuli (such as IFN- $\gamma$ ), IDO is primarily produced by antigen presenting cells (APCs) and has several immunosuppressive effects, thus maintaining the balance between pro- and antiinflammatory impulses. The rate of TRP degradation, expressed by the ratio of KYN to TRP (K/T), allows a good estimate of its enzymatic activity [34]. The induction of IDO and the kynurenine system results in the inhibition of $\mathrm{T}$ cell functions, the activation of regulatory $\mathrm{T}$ cells, and the inhibition of natural killer cells. The alterations of the kynurenine system appear to play a role in the pathophysiology of a broad spectrum of neurological disorders [35], including ischemic brain injury; however, its role has previously not been investigated in perinatal asphyxia.

The challenge in neonatal asphyxia is to harness the beneficial aspects of neuroinflammation following the insult to allow neuroprotection and regeneration within the CNS while at the same time minimizing its harmful effects. Significant barriers remain in understanding the benefits of inflammation in contrast to its detriments following neonatal asphyxia. Identification of factors that differentiate between infants with an extensive and potentially damaging neuroinflammatory response and infants with moderate inflammation would present new options for a more individualized therapeutic approach in neonatal asphyxia. In this study, we aimed to assess the prevalence and cytokine production of $\mathrm{T}$ lymphocyte subsets in moderate and severe perinatal asphyxia in order to identify players of the inflammatory response that may influence patient outcome. In contrast to previous studies, we aimed to determine the intracellular cytokine levels of $\mathrm{T}$ lymphocytes besides plasma cytokine levels. We also aimed to describe plasma TRP, KYN, and KYNA levels. We also expanded our investigation to 1 month of age following the CNS insult to understand longer-term consequences of the hypoxic event.

\section{Methods}

\section{Patients}

We enrolled 33 term neonates admitted to the regional neonatal intensive care unit at the First Department of
Pediatrics at Semmelweis University, Budapest, Hungary, with the initial diagnosis of perinatal asphyxia requiring therapeutic hypothermia. The diagnosis of moderate-tosevere hypoxic-ischemic encephalopathy and the eligibility for cooling was assessed according to the TOBY criteria [36]. Infants fulfilled both criteria A (Apgar score $\leq 5$ at $10 \mathrm{~min}$ after birth OR continued need for resuscitation, including endotracheal or mask ventilation, at $10 \mathrm{~min}$ after birth OR umbilical cord, arterial, or capillary $\mathrm{pH}<7.00$ within 60 min of birth OR base deficit $\geq 16 \mathrm{mmol} / \mathrm{L}$ in umbilical cord or any blood sample (arterial, venous, or capillary) within $60 \mathrm{~min}$ of birth) AND criteria B (clinical seizures OR altered state of consciousness (reduced response to stimulation or absent response to stimulation) AND abnormal tone (focal or general hypotonia, or flaccid) AND abnormal primitive reflexes (weak or absent suck or Moro response)). All enrolled neonates were outborn, and hypothermia was initiated between 1 and $5 \mathrm{~h}$ of life (mostly within $2 \mathrm{~h}$ of life as hypothermia was started before and maintained during transport). Rectal temperature was maintained between 33 and $34{ }^{\circ} \mathrm{C}$ and was recorded every hour during the $72 \mathrm{~h}$ intervention period. Two-milliliter venous blood samples were collected between 3 and $6 \mathrm{~h}$ of life (at admission), as well as at $24 \mathrm{~h}, 72 \mathrm{~h}$, and 1 week of life during intensive care treatment, adjusted to blood sampling related to clinical care. A further venous blood sample was obtained at 1 month of age during a routine outpatient follow-up appointment.

Neonates with congenital abnormalities or CNS malformations, maternal chorioamnionitis or perinatal infections were excluded from the study. Blood cultures and ear swabs were obtained at admission from all infants, and bacterial infection was excluded. Clinical or culture-proven sepsis was not detected in any of the participating infants. All infants received regular preventive intravenous antibiotics, i.e., ampicillin and gentamicin, during the hypothermic treatment. Four infants were excluded from the analysis as their MRI scan results showed signs of neonatal stroke rather than a hypoxicischemic insult. One further infant was excluded due to suspected metabolic disease (peroxisomal fatty acid C26/ C22 ratio above the normal range) as well as the presence of multiple minor anomalies and mutation of the ROBO1 gene. Therefore, data from 28 neonates are analyzed in this study. Participating neonates were divided into two groups based on the severity of hypoxicischemic insult, determined by initial and recovery time of amplitude-integrated EEG (aEEG) monitoring [37] as well as MRI results performed up to 12 days of life. MRI data were interpreted by radiologists who were blinded to the clinical status of the neonates, based on the criteria defined by Marcovici et al. and Bosmans et al. $[38,39]$. The reporting template was developed in the 
ISORT (intelligent structured online reporting tool) software framework created by Bioscreen Ltd., Debrecen, Hungary. In cases where MRI was not performed due to the critical condition of the patient or MRI data were missing, grouping was done solely based on the aEEG results. The severe group $(n=11)$ consisted of newborns with moderate-to-severe hypoxic-ischemic encephalopathy (HIE) signs on MRI scans AND burst-suppression or continuous extremely low voltage or flat tracing background activity on aEEG OR normalization of aEEG after the 48th hour of life or never, OR early death $(<28$ days). Neonates that met none of the abovelisted criteria constituted the moderate group $(n=17)$ (normal MRI scans or mild HIE signs on MRI scans AND continuous or discontinuous normal voltage background activity on aEEG OR normalization of aEEG activity before the 48th hour of life).

In the severe group, three infants deceased before 1 month of age due to the severity of the insult. Available data from these neonates were included at the relevant time points within the severe group. Therefore, 72-h, 1-week, and 1-month data were missing in case of two infants, and 1-month data were missing from one infant.

Our study was reviewed and approved by the Hungarian Medical Research Council (TUKEB 6578-0/2011-EKU), and written informed consent was obtained from parents of all participants. The study was adhered to the tenets of the most recent revision of the Declaration of Helsinki. Clinical characteristics and laboratory parameters of participants are summarized in Table 1.

\section{Flow cytometry}

Plasma was separated from peripheral blood samples by centrifugation. Plasma samples were aliquotted and immediately frozen and stored at $-80{ }^{\circ} \mathrm{C}$ for later determination of cytokine concentrations and HPLC measurements.

Remaining cells were resuspended in RPMI (Roswell Park Memorial Institute)-1640 medium (Sigma-Aldrich, St. Louis, MO, USA). Cells were incubated with PMA (phorbol 12-myristate 13-acetate) $(50 \mathrm{ng} / \mathrm{ml})$, ionomycin $(1 \mu \mathrm{g} / \mathrm{mL})$, and BFA (brefeldin A) $(10 \mu \mathrm{g} / \mathrm{ml})$ for $6 \mathrm{~h}$ at $37^{\circ} \mathrm{C}$ to allow intracellular accumulation of cytokines. For surface marker staining, samples were then incubated with the following fluorochrome-conjugated anti-human monoclonal antibodies: CD4 PE-Cy7 (phycoerythrin-cyanine 7) and CD8 APC-Cy7 (allophycocyanin-cyanine 7) (panel 1) or CD4 APC-Cy7 and CD49d PerCP (peridinin-chlorophyll-protein) (panel 2), respectively, according to the manufacturers' instructions (all from BioLegend, San Diego, CA, USA). Red blood cells were lysed and PBMCs were permeabilized
Table 1 Clinical characteristics of neonates in the moderate and severe groups upon admission (within $12 \mathrm{~h}$ of age)

\begin{tabular}{|c|c|c|}
\hline & $\begin{array}{l}\text { Moderate group } \\
(n=17)\end{array}$ & $\begin{array}{l}\text { Severe group } \\
(n=11)\end{array}$ \\
\hline Male gender (\%) & $10(59)$ & $7(64)$ \\
\hline Birthweight (g) & $3330(2860-3605)$ & $3000(2490-3300)$ \\
\hline Gestational age (week) & $39(37-40)$ & $38(37-40)$ \\
\hline No. of C-sections (\%) & $10(59)$ & $8(73)$ \\
\hline Apgar at $1 \mathrm{~min}$ & $3(0.5-4.5)$ & $1(0-3)$ \\
\hline Apgar at $5 \mathrm{~min}$ & $6(5-7)$ & $2^{*}(0-4)$ \\
\hline Apgar at $10 \mathrm{~min}$ & $7(5-8)$ & $4^{*}(1.75-5.25)$ \\
\hline Worst pH (within first $12 \mathrm{~h}$ ) & $7.025(6.874-7.12)$ & $6.86(6.62-7.058)$ \\
\hline $\begin{array}{l}\text { Worst BD (within first } 12 \mathrm{~h} \text { ) } \\
(\mathrm{mmol} / \mathrm{L})\end{array}$ & $18.05(16.65-21.275)$ & $20.4(19.375-23.5)$ \\
\hline Need for inotropes (\%) & $8(44)$ & $8^{*}(73)$ \\
\hline Need for hydrocortisone (\%) & $5(36)$ & $5(45)$ \\
\hline $\begin{array}{l}\text { Need for erythrocyte } \\
\text { transfusion (\%) }\end{array}$ & $7(41)$ & $4(36)$ \\
\hline $\begin{array}{l}\text { Need for platelet } \\
\text { transfusion (\%) }\end{array}$ & $2(11)$ & $1(9)$ \\
\hline $\begin{array}{l}\text { Need for fresh } \\
\text { frozen plasma (\%) }\end{array}$ & $6(35)$ & $10^{*}(91)$ \\
\hline S100 (ug/L) & $7.48(2.33-28.85)$ & $21.8(3.8-30.0)$ \\
\hline $\mathrm{LDH}(\mathrm{U} / \mathrm{L})$ & $2072(1371-5274)$ & $3335(1879-5792)$ \\
\hline Uric acid (umol/L) & $530(474.5-576.5)$ & $593(443-634)$ \\
\hline AST (U/L) & $112(79-363)$ & $207(128-438)$ \\
\hline $\mathrm{ALT}(\mathrm{U} / \mathrm{L})$ & $24(19-125)$ & $54(29-148)$ \\
\hline GGT (U/L) & $123(73-198)$ & $97(47-197)$ \\
\hline Urea (mmol/L) & $4.9(3.7-5.3)$ & $4.8(3.9-5.7)$ \\
\hline Creatinine (umol/L) & $88(78.5-99)$ & $105(80-114)$ \\
\hline
\end{tabular}

Data are presented as median (IQR)

${ }^{*} p<0.05$ vs Moderate group

using FACSLysing and FACSPermeabilizing solutions (BD Biosciences, San Jose, CA, USA). Cells were washed and resuspended in PBS (phosphate buffer saline) and divided into two equal aliquots and stained according to the manufacturers' instructions for intracellular cytokines using the following conjugated anti-human monoclonal antibodies or the appropriate isotype controls: IL-6 PE (phycoerythrin), IL-17A PerCP, IL-10 APC (allophycocyanin), and IFN- $\gamma$ FITC (fluorescein isothiocyanate) (for panel 1) or TNF- $\alpha$ PE-Cy7, FoxP3 PE, TGF- $\beta$ APC, and IL-1 $\beta$ FITC (for panel 2), respectively (all from BioLegend). Following labeling, cells were washed and resuspended in PBS for flow cytometry analysis. Samples were analyzed immediately on a FACSAria flow cytometer (BD Biosciences) equipped with 488 and $633 \mathrm{~nm}$ excitation lasers. Data were processed using the FACSDiVa software (BD Biosciences). One hundred thousand cells were recorded. Evaluators of flow cytometry data were blinded to the clinical status of the neonates. 


\section{Immunoassays}

Plasma samples were stored at $-80{ }^{\circ} \mathrm{C}$ until analysis. The plasma levels of the following cytokines, chemokines, and growth factors were determined using Bio-Plex Pro Assays (Bio-Rad Laboratories, Hercules, CA, USA): IL-1b, IL-2, IL-4, IL-5, IL-6, IL-7, IL-8, IL-10, IL12 , IL-13, IL-17, IFN- $\gamma$, TNF- $\alpha$, TGF- $\beta$, G-CSF, GM-CSF, MCP-1, MIP-1b, and VCAM. Bio-Plex Pro Assays are immunoassays formatted on magnetic beads that utilize principles similar to those of a sandwich ELISA. Capture antibodies against the biomarker of interest are covalently coupled to the beads. A biotinylated detection antibody creates the sandwich complex, and the final detection complex is formed by the addition of a streptavidin-phycoerythrin (SA-PE) conjugate, where PE serves as the fluorescent reporter. Reactions are read using a Luminex-based reader.

\section{High-performance liquid chromatography}

Plasma samples were stored at $-80{ }^{\circ} \mathrm{C}$ until analysis. Directly prior to analysis, samples were thawed, vortexed, and $300 \mu \mathrm{l}$ of plasma was "shot" onto $700 \mu \mathrm{l}$ of precipitation solvent (containing $3.57 \mathrm{w} / \mathrm{w} \%$ perchloric acid and $2.857 \mathrm{mM}$ 3-nitro-L-tyrosine as internal standard (Scharlau, Barcelona, Spain)). Samples were then centrifuged $\left(13,000 \mathrm{~g}\right.$ for $10 \mathrm{~min}$ at $\left.4{ }^{\circ} \mathrm{C}\right)$, and the supernatants were collected. For the quantification of KYN, KYNA, and TRP concentrations of samples, a modified method based on Herve et al. [40] was utilized, using an Agilent 1100 HPLC system (Agilent Technologies, Santa Clara, CA, USA). The system was equipped with a fluorescent detector, which was used to determine the concentration of KYNA and TRP, and a UV detector which was applied for the determination of KYN and the internal standard. Chromatographic separations were performed on an Onyx monolithic C18 column, $100 \times 4.6 \mathrm{~mm}$ I.D. (Phenomenex Inc., Torrance, CA, USA) after passage through a Hypersil ODS precolumn, $20 \times 2.1 \mathrm{~mm}$ I.D., $5-\mu \mathrm{m}$ particle size (Agilent Technologies) with a mobile phase composition of $0.2 \mathrm{M}$ zinc acetate/acetonitrile $95 / 5 \mathrm{v} / \mathrm{v} \%$ with a $\mathrm{pH}$ adjusted to 6.2 with glacial acetic acid, applying isocratic elution. The flow rate and the injection volume were $1.5 \mathrm{~mL} / \mathrm{min}$ and $20 \mu \mathrm{L}$, respectively. The fluorescent detector was set at excitation and emission wavelengths of 344 and $398 \mathrm{~nm}$, and after $3.5 \mathrm{~min}$ of each run, the wavelengths were changed to 254 and $398 \mathrm{~nm}$. The UV detector was set at a wavelength of $365 \mathrm{~nm}$. L-TRP, L-KYN sulfate salt, KYNA, and zinc acetate dihydrate were purchased from Sigma-Aldrich, and acetic acid was purchased from VWR International (Radnor, PA, USA).

\section{Statistical analysis}

Data are expressed as median and interquartile range. Comparisons between sample populations were performed with Mann-Whitney tests, as a test of normality (performed according to Kolmogorov-Smirnoff) indicated the non-normal distribution of data. Comparisons between the paired values (samples collected at different time points) in the same population were made with Friedman tests. $p$ values less than 0.05 were considered significant. Outliers were identified using Grubbs' tests and were excluded from the analyses. Statistics were calculated using the GraphPad Prism 5 software (La Jolla, CA, USA).

\section{Results}

IL-1 $\beta$

Our results suggest that CD4+ IL-1 $\beta+$ cells are early mediators of the inflammatory response, as their prevalence is higher at $6 \mathrm{~h}$ after birth in severe compared to moderate asphyxia. The extravasation of these cells is also increased at this time point in severe asphyxia as evidenced by the lower prevalence of CD49d-expressing CD4+ IL- $1 \beta+$ cells in peripheral blood. Therefore, although plasma levels of IL-1 $\beta$ are not different in moderate and severe asphyxia, IL-1 $\beta$ may play an important role in initiating tissue damage in the brain following the hypoxic insult. Intracellular (MFI) levels of IL-1 $\beta$ in both groups and plasma levels in the moderate group are highest at $6 \mathrm{~h}$ and comparably lower at the following time points, suggesting that its main role is the initiation of the inflammatory response (Table 2 and Figs. 1 and 2).

\section{IL-6}

Plasma IL-6 levels were higher at 1 week in the severe compared with the moderate group. Plasma IL-6 levels decreased by 1 month following the insult in the moderate group. Mean fluorescence intensity (MFI) of CD4+ IL-6+ cells peaked at $24 \mathrm{~h}$ in both patient groups and declined later, indicating that it may play a role in the initial inflammatory response. MFI of CD8+ IL-6+ cells in the severe group also decreased by 1 week (Table 2 and Figs. 1 and 2).

\section{IL-17}

The prevalence of CD8+ IL-17+ cells was higher in the moderate group than in the severe group at $6 \mathrm{~h}$. In contrast, the prevalence of CD4+ IL-17+ cells was lower in the moderate than in the severe group at 1 week The prevalence of CD4+ IL-17+ was lower at $6 \mathrm{~h}$ than at other time points in the severe group and remained high until 1 month. MFI of CD8+ IL-17+ cells at $24 \mathrm{~h}$ and that of CD4+ IL-17+ cells at $72 \mathrm{~h}$ were also higher in the severe group. The MFI of CD8+ IL-17+ cells peaked at $72 \mathrm{~h}$ in the moderate group. No difference was observed in plasma levels of IL-17 (Table 2 and Figs. 1 and 3). 
Table 2 Significant differences in intracellular cytokine, plasma cytokine, and high-performance liquid chromatography (HPLC) data between the moderate and severe group

\begin{tabular}{|c|c|c|c|}
\hline & Time & Moderate & Severe \\
\hline \multicolumn{4}{|c|}{ Intracellular cytokines_cell prevalence data (\% of parent population) } \\
\hline CD4+ IL-1b+/CD4+ & $6 \mathrm{~h}$ & $3.52(2.13-5.16)$ & $6.77(3.18-10.26)$ \\
\hline CD4+ IL-1b+CD49d+/CD4+ IL-1b+ & $6 \mathrm{~h}$ & $6.98(4.61-9.32)$ & $4.08(2.86-5.46)$ \\
\hline CD4+ TNF-a + CD49d+/CD4+ TNF-a+ & $6 \mathrm{~h}$ & $6.63(4.47-13.45)$ & $3.52(2.12-7.23)$ \\
\hline CD8+ IL-17+/CD8+ & $6 \mathrm{~h}$ & $5.26(3.89-14.40)$ & $2.63(1.75-5.18)$ \\
\hline CD4+ FoxP3+/CD4+ & $24 \mathrm{~h}$ & $2.35(1.96-3.13)$ & $3.02(2.60-4.13)$ \\
\hline CD4+ TNF-a+ CD49d+/CD4+ TNF-a+ & $72 \mathrm{~h}$ & $4.77(3.43-7.70)$ & $9.75(6.31-10.80)$ \\
\hline CD4+ IL-17+/CD4+ & 1 week & $3.08(1.80-4.59)$ & $5.13(3.40-13.76)$ \\
\hline \multicolumn{4}{|c|}{ Intracellular cytokines_-mean fluorescence intensity (MFI) data (arbitrary unit) } \\
\hline CD8+ IL-17+/CD8+ & $24 \mathrm{~h}$ & $1069(639-3265)$ & $4187(1274-6133)$ \\
\hline $\mathrm{CD} 4+\mathrm{IFN}-\mathrm{g}+/ \mathrm{CD} 4+$ & $72 \mathrm{~h}$ & $455(150-770)$ & $887(496-1427)$ \\
\hline CD4+ IL-17+/CD4+ & $72 \mathrm{~h}$ & $939(566-1674)$ & $1760(1614-3508)$ \\
\hline CD4+ TNF-a+/CD4+ & 1 month & $3281(1752-4326)$ & 4729 (3959-6714) \\
\hline \multicolumn{4}{|l|}{ Plasma cytokines (pg/mL) } \\
\hline G-CSF & $24 \mathrm{~h}$ & $19.85(10.87-30.70)$ & $42.74(22.27-131.3)$ \\
\hline IL-5 & $72 \mathrm{~h}$ & $1.37(0.00-4.69)$ & $0.20(0.00-0.46)$ \\
\hline IL-13 & $72 \mathrm{~h}$ & $2.35(2.01-3.67)$ & $1.70(1.40-2.56)$ \\
\hline IL-6 & 1 week & 21.06 (11.89-43.24) & $70.25(33.73-134.1)$ \\
\hline G-CSF & 1 week & $13.33(5.52-17.72)$ & $32.90(16.65-94.76)$ \\
\hline \multicolumn{4}{|l|}{ HPLC results (uM) } \\
\hline KYN & 1 month & $3.62(2.72-4.47)$ & $2.28(1.45-3.14)$ \\
\hline
\end{tabular}

\section{TNF-a}

On the contrary, MFI of TNF- $\alpha$ in CD4 cells was increased at all time points compared to $6 \mathrm{~h}$ in both groups. At 1 month, MFI of TNF- $\alpha$ was higher in the severe group, suggesting that it might play a role in the development of long-term consequences of asphyxia. The prevalence of CD49d-expressing CD4+ TNF- $\alpha+$ cells is lower in severe asphyxia at $6 \mathrm{~h}$ compared to later time points, indicating that in a severe insult, it might also contribute to early tissue destruction through increased extravasation. This is further supported by the fact that the prevalence of CD49d-expressing CD4+ TNF- $\alpha+$ cells is lower at $6 \mathrm{~h}$ and higher at $72 \mathrm{~h}$ in severe asphyxia compared to a moderate insult. No difference was observed in plasma levels of TNF- $\alpha$ (Table 2 and Figs. 1 and 3).

\section{Other pro-inflammatory cytokines}

MFI of CD4+ IFN $-\gamma+$ cells was higher in the severe than in the moderate group at $72 \mathrm{~h}$. Plasma MCP-1 levels were higher at 24 and $72 \mathrm{~h}$ as well as 1 week than at $6 \mathrm{~h}$ in the moderate group. Plasma G-CSF levels were higher at $24 \mathrm{~h}$ and 1 week in the severe compared with the moderate group. G-CSF levels decreased by 1 week and remained low at 1 month following the initial insult in the moderate group (Table 2 and Fig. 2).

\section{TGF- $\beta$}

The prevalence of CD49d-expressing CD4+ TGF- $\beta+$ cells was increased at 1 week and 1 month compared to $72 \mathrm{~h}$ in the moderate group potentially indicating that TGF- $\beta$ plays an anti-inflammatory role in tissue regeneration in the early stage of the insult. MFI of CD4+ TGF- $\beta+$ cells was increased from $24 \mathrm{~h}$ onwards in the moderate but not in the severe group, which is probably also part of a compensatory phenomenon (Figs. 1 and 3).

\section{Other anti-inflammatory cytokines}

Plasma IL-10 levels were lower at 1 month than at 6 and $24 \mathrm{~h}$ in the moderate group. Plasma IL-13 and IL-5 levels were higher in the moderate than in the severe group at $72 \mathrm{~h}$. Plasma IL-13 levels were higher at 6 and $24 \mathrm{~h}$ than the following time points in the severe group (Table 2 and Fig. 2).

\section{Tregs}

The prevalence of Tregs is somewhat higher in severe asphyxia at $24 \mathrm{~h}$, which might be part of a compensatory 


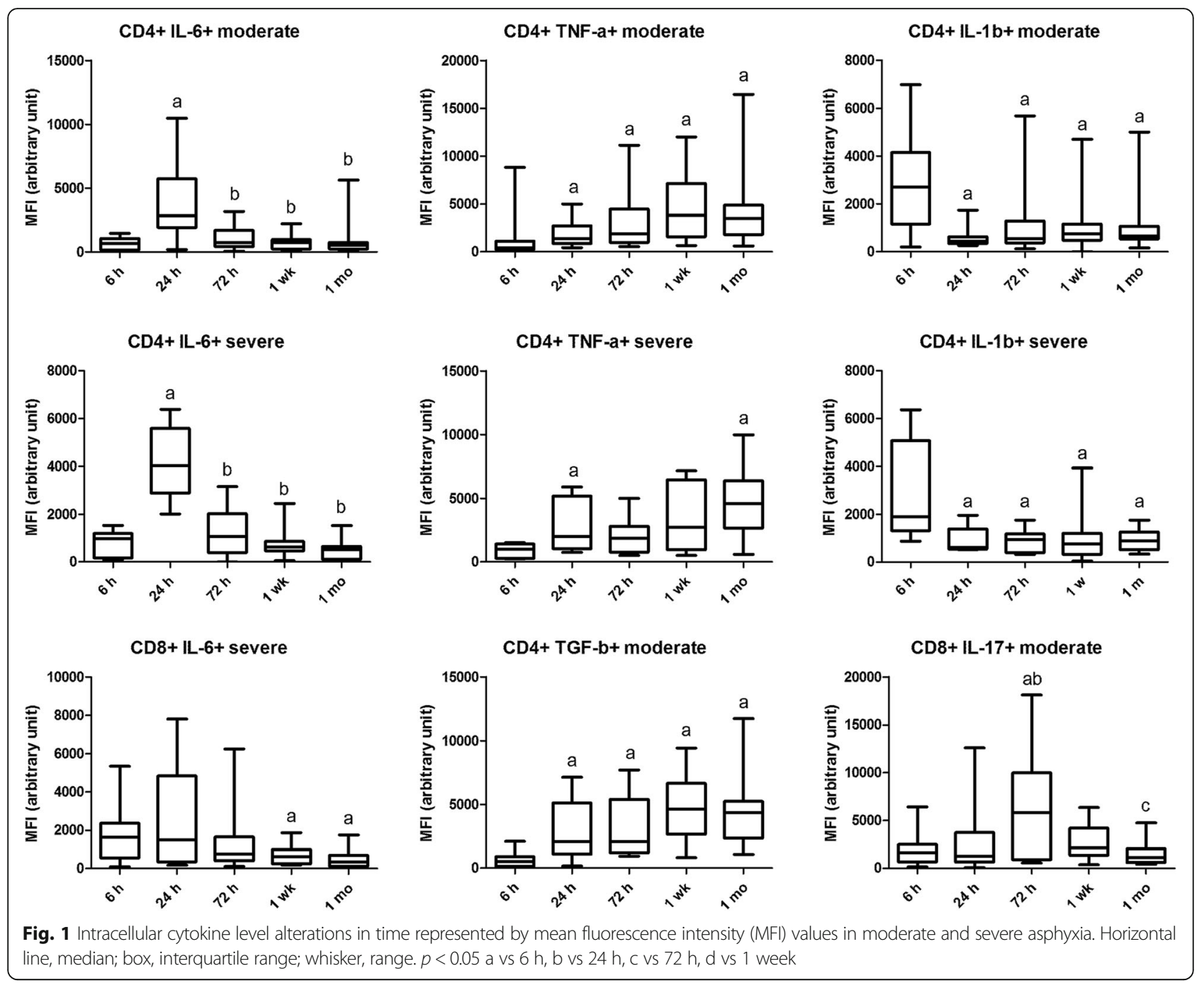

mechanism; however, the biological significance of this increase is questionable (Table 2).

\section{The kynurenine system}

Plasma KYN levels were higher at 1 month in the moderate group compared to the severe group. KYN levels showed a decline in both groups by 1 week and 1 month following the insult. Similar results were observed for KYNA, while TRP levels increased significantly by 1 month in both groups. In line with the above, the K/T ratio, corresponding to the enzymatic activity of IDO, plummeted by 1 month in both groups (Table 2 and Fig. 4).

\section{ROC analysis}

We performed ROC analyses to assess which parameters have the potential to discriminate between a moderate and a severe insult at an early stage. The only significant results of the ROC analyses were related to intracellular IL-1 $\beta$. The prevalence of CD4+ IL- $1 \beta+$ cells at $6 \mathrm{~h}(p=0.018, \mathrm{ROC}$ AUC $=0.784)$ and that of CD4+ IL-1 $\beta+$ CD49d+ cells at $6 \mathrm{~h}(p=0.027$, ROC AUC $=0.767)$ was able to differentiate severity with a reasonable sensitivity and specificity (Fig. 5).

\section{Discussion}

Several studies have described the importance of cytokines in normal neuronal differentiation and survival [41-43]. The perinatal brain might be particularly susceptible to alterations in cytokine concentrations, and experimental data suggest that cytokines play a pivotal role in the regulatory network orchestrating neuroinflammation [44]. Cytokines have been in the limelight of research focusing on asphyxia. The inflammatory response following hypoxic brain injury has been shown to have dual effects. A certain level of inflammation appears to be necessary for the adequate regeneration of the brain tissue [6], while extensive neuroinflammation might contribute to further CNS injury and be an important factor in worse functional outcome. We aimed therefore to determine factors that might differentiate 


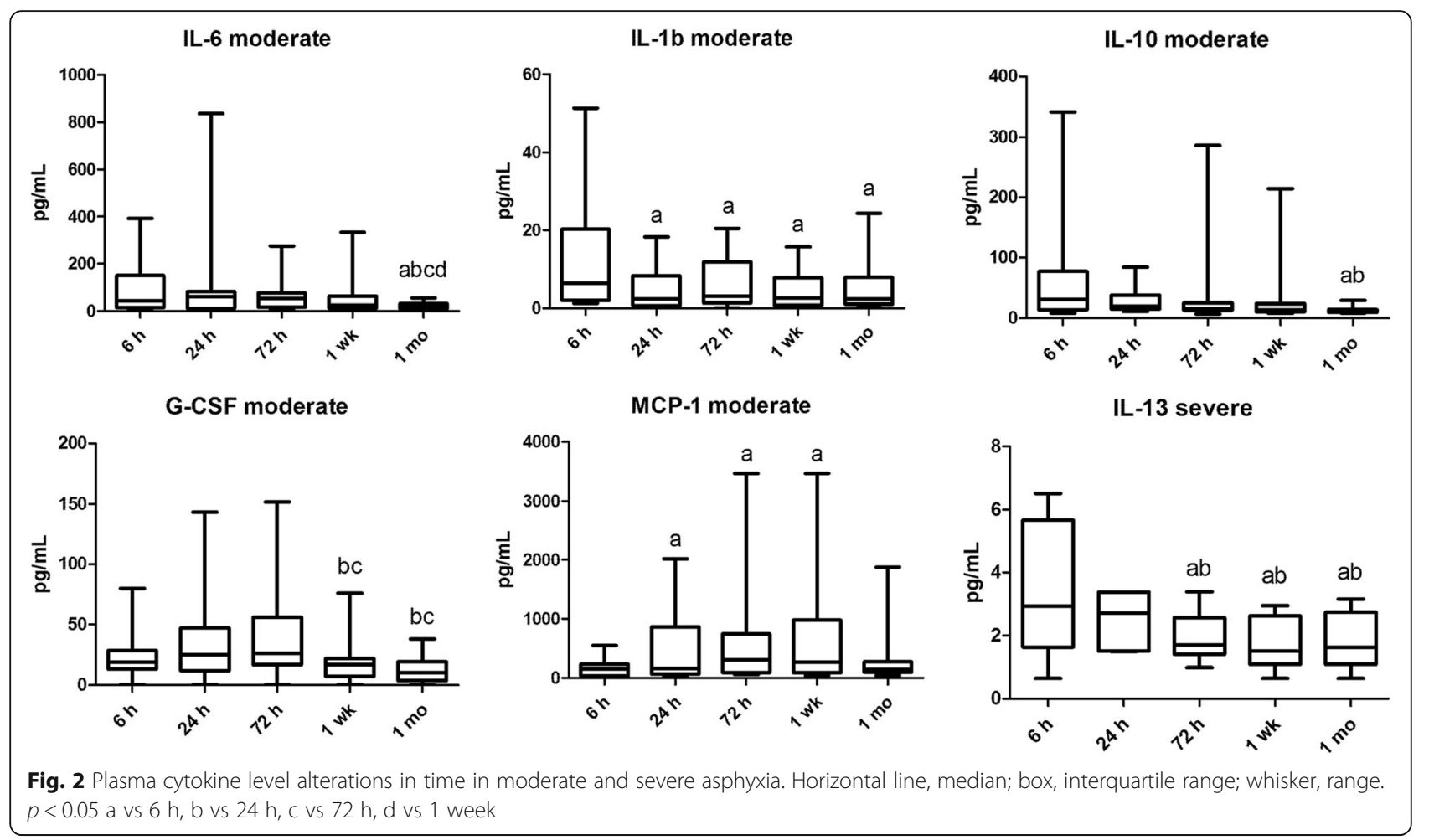

between infants who have an adequate level of inflammatory response which is necessary for neuroregeneration from infants in whom the uncompensated inflammatory response contributes to brain injury. Previous studies have focused on determining the level of cytokines from plasma. However, plasma cytokine levels have been shown to have a great variability compared with intracellular cytokine levels, which closely reflect cytokine production at a cellular level and show more stable kinetics in time, and thus open new possibilities for more precise characterization of the cytokine network in immune disorders. The relationship between cellular cytokine production and serum cytokine levels is undefined; cytokines in the serum originate from various different sources and show less stable kinetics. The advantage of intracellular cytokine analysis by flow cytometry is that with this method, the cytokine production of each cell type can be accurately described. This method opens up the opportunity for precise characterization of the function of each cell type in a physiological setting (i.e., maintaining autocrine and cell-cell interactions), which could be of great value in identifying key cellular players of various inflammatory conditions $[45,46]$. We therefore primarily aimed to describe intracellular cytokine values; however, we also measured cytokine levels from plasma to gain a more comprehensive picture of the immunologic alterations following the hypoxic insult. Furthermore, contrary to previous studies, we expanded sampling of infants to 1 month of age to obtain data on

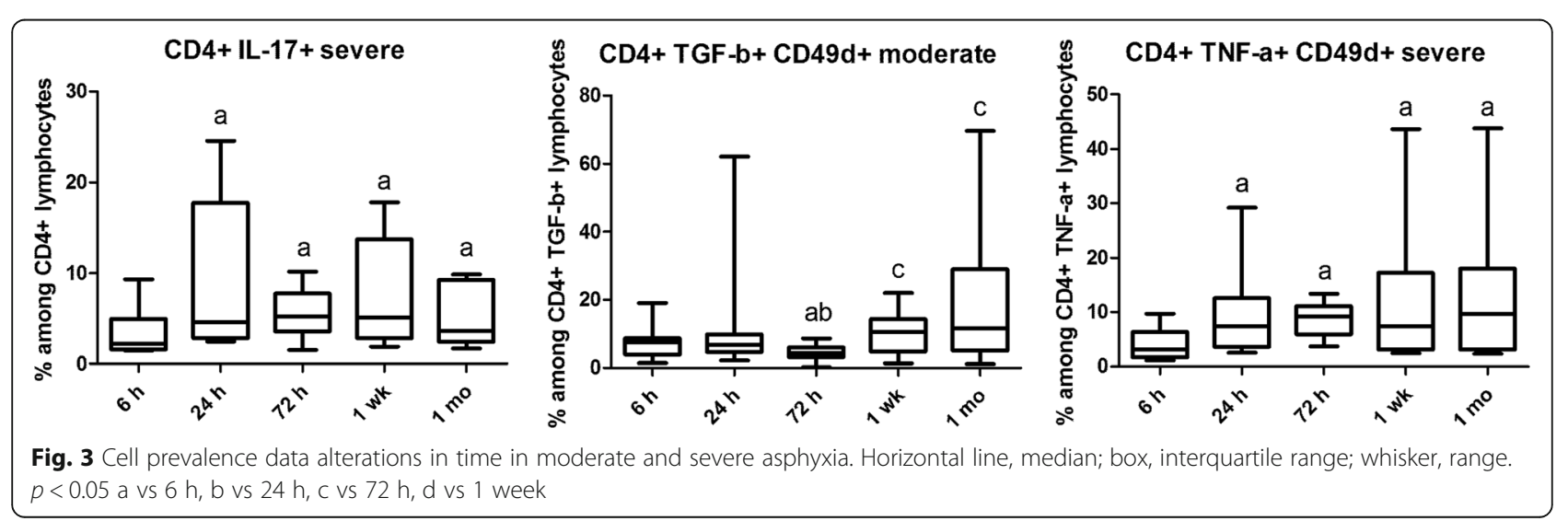




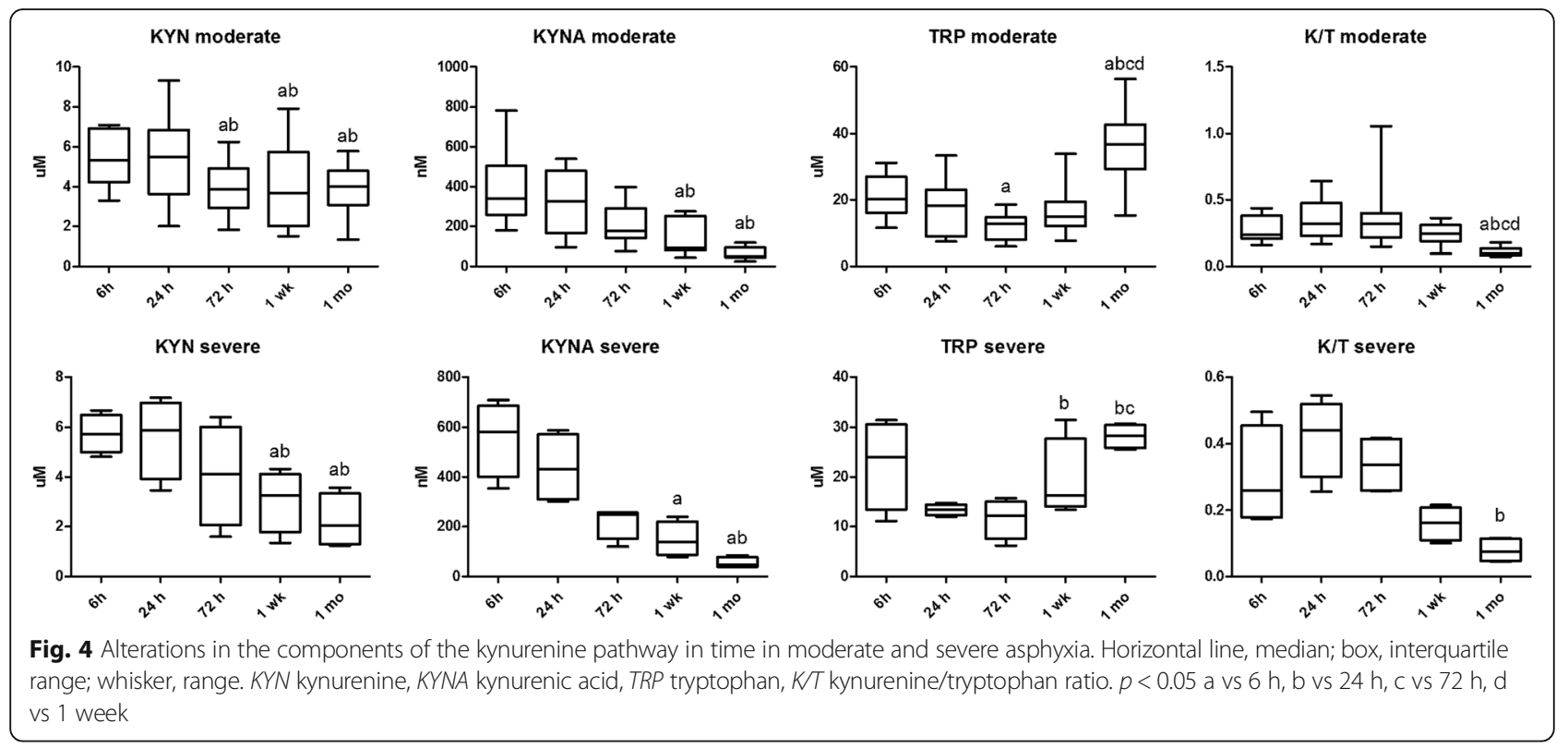

longer-term changes in inflammatory parameters evoked by asphyxia.

\section{IL-1 $\beta$}

IL-1 $\beta$ is an important mediator of pro-inflammatory responses [47] and has been reported to have neurotoxic properties leading to BBB breakdown and apoptotic neuronal death $[48,49]$. Aly et al. found that the CSF level of IL-1 $\beta$ in term neonates had the highest predictive value of poor neurologic outcome in asphyxia after 6 and 12 months and suggested the central role of IL-1 $\beta$ in the ongoing neuronal injury that occurs in the latent phase following the original hypoxic insult [16]. They also found a high CSF to plasma ratio of IL-1 $\beta$, indicating elevated local production of the cytokine in the CNS. Several animal models also suggest that IL-1 $\beta$ contributes to the brain injury $[50,51]$. The exacerbation of ischemic brain injury has also been observed following exogenous administration of IL-1 $\beta$. Other studies demonstrated that the deficiency of IL- $1 \beta$ converting enzyme or treatment with IL-1 receptor antagonists (IL-1ra) resulted in the moderation of hypoxic brain injury [52, 53], decreased post-ischemic edema [49], and improved neurological outcome [54].

The primary sources of IL- $1 \beta$ are APCs and monocytes $[55,56]$, although microglia and endothelial cells are also capable of producing IL- $1 \beta[57,58]$. The fact that $\mathrm{T}$ lymphocytes are able to produce physiologically relevant amounts of IL-1 $\beta$ and that it plays an important role in their functionality has only recently been revealed [59]. In this study, we observed significant IL- $1 \beta$ production in $\mathrm{T}$ lymphocytes in neonatal asphyxia, which was more pronounced in a severe insult. In line with the previous findings [16], our current results suggest that CD4 + IL- $1 \beta+$ cells might play an important role in initiating tissue damage in the brain following the hypoxic insult.

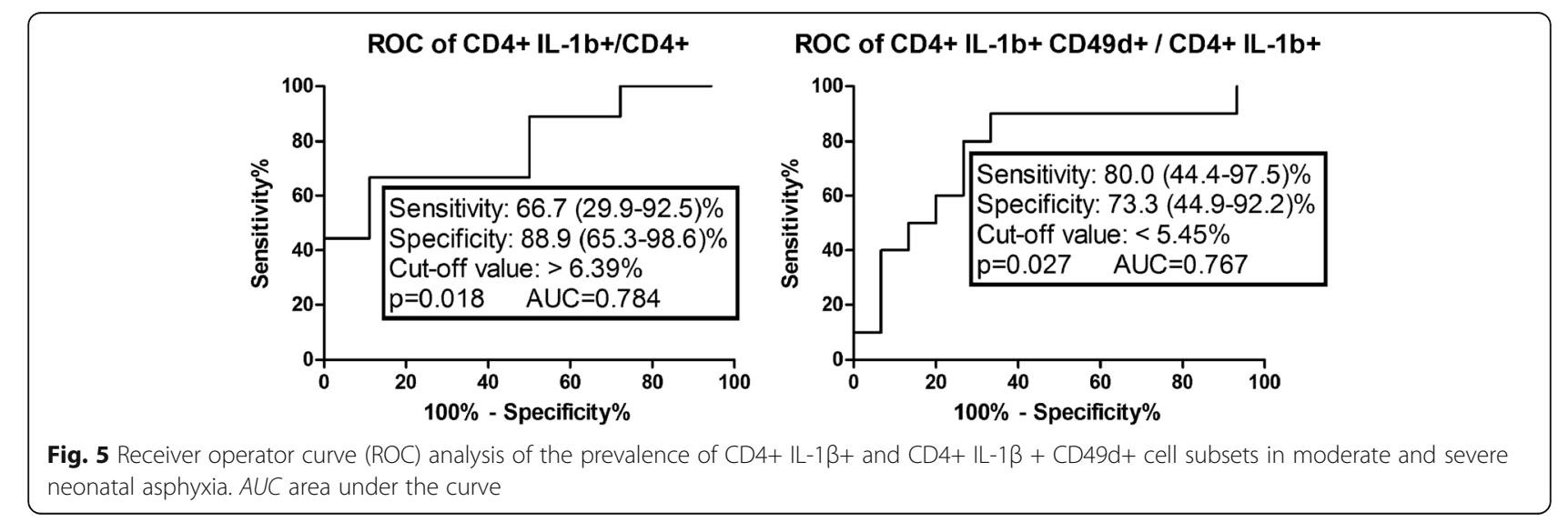


However, intracellular concentrations of IL- $1 \beta$ gradually decreased in both patient groups, suggesting that a certain level of initial increase may be necessary for the regenerative processes as well. Based on our ROC analysis, the prevalence of IL- $1 \beta$-producing CD4+ T cells may be useful in the differentiation of the severity of the insult at an early stage, up to $6 \mathrm{~h}$ after birth (Fig. 5). The notable amount of data showing the therapeutic benefits of peripheral administration of IL-1ra following ischemic brain injury [60] and the fact that IL-1 receptor antagonistic agents are already available in clinical use in autoimmune disorders prompts further research to explore whether IL- $1 \beta$ levels above a certain threshold may be a potential future therapeutic target in neonatal asphyxia.

\section{IL-6}

Several previous studies have associated elevated IL-6 CSF levels with poor neurological outcome, cerebral palsy, and death in asphyxia $[44,61]$. However, Aly et al. suggested that IL- 6 might have neurotrophic as well as neuroprotective, anti-inflammatory effects via inhibiting the synthesis of TNF- $\alpha$ and IL-1 $\beta[16,62]$. They found highly elevated IL-6 CSF to plasma ratios, and MartinAncel et al. also concluded that IL-6 appears to be primarily produced intrathecally following the ischemic brain injury while diffusion from the plasma is secondary [44]. In this study, we found that plasma IL-6 levels were elevated in severe compared to moderate asphyxia at 1 week and decreased in moderate, but not in severe asphyxia by 1 month. Intracellular levels of IL- 6 in CD4+ cells peaked at $24 \mathrm{~h}$ in both patient groups and declined later. However, we found no alterations in intracellular cytokine levels or cellular prevalence data between the two study groups, suggesting that CSF levels of IL-6 might be of more importance with regard to its deleterious effects.

\section{IL-17}

IL-17 is a pro-inflammatory cytokine produced primarily by Th17 cells upon IL-23 stimulation [63]. IL-17 has been shown to play a pivotal role in the delayed progression of brain infarction following hypoxic injury in a mouse brain ischemia model. This is further supported by the fact that IL-17KO mice show a significant reduction in the infarcted area and apoptotic neuronal death from the fourth post-stroke day onwards [64]. Yang et al. reported a significant influx of Th17 cells into the brain tissue in hypoxic-ischemic encephalopathy following LPS (lipopolysaccharide)-sensitization both in neonates and in newborn rats [65]. In line with the previous findings in mouse models, we observed a delayed increase in the prevalence and cytokine production of IL-17 producing $\mathrm{T}$ cells, which remained elevated in the severe group during the whole observation period. The prevalence of Th17 lymphocytes was higher in the severe group than in the moderate group at 1 week. IL-17 could play an important role in maintaining the chronic neuroinflammation leading to detrimental consequences.

\section{TNF- $a$}

TNF- $\alpha$ is a pro-inflammatory cytokine which stimulates the production of IL-1 $\beta$ and among other cytokines regulates the apoptosis of CNS cells, promotes leukocyte differentiation, proliferation, and subsequent CNS infiltration $[66,67]$. There is an extensive amount of data supporting the role of TNF- $\alpha$ in ischemic brain damage [52, 68-71]. The level of TNF- $\alpha$ in the CNS has been shown to peak 6-12 h following the hypoxic-ischemic injury in newborn rats [61]. Increased TNF- $\alpha$ and IL-1 $\beta$ plasma and CSF levels in term infants with asphyxia have been associated with neuroradiological alterations, poor neurological status at 12 months of age, and cerebral palsy [72, 73]. Blocking TNF- $\alpha$, for example, by the administration of pentoxifylline, a competitive inhibitor of TNF- $\alpha$, improved neurological outcome by attenuating ICAM1 expression, reducing the disruption of the $\mathrm{BBB}$ and protecting neurons from delayed cell death in animal models of head trauma [74].

In line with the previous findings, we found that the MFI of TNF- $\alpha$ in CD4 cells was increased in both groups at all time points compared to $6 \mathrm{~h}$, suggesting a delayed increase in production of TNF- $\alpha$ by T cells following the insult. In severe asphyxia, we observed higher MFI of TNF- $\alpha$ at 1 month than in moderate asphyxia, which might indicate that TNF- $\alpha$ plays a role in maintaining a chronic inflammatory response in severe asphyxia, thus contributing to long-term consequences. We found increased extravasation of TNF- $\alpha$ producing cells at $6 \mathrm{~h}$ (indicated by the decreased prevalence of CD49d-expressing CD4+ TNF- $\alpha+$ cells), which may indicate the role of TNF- $\alpha$ in determining the extent of the initial tissue injury as well. At later time points, we found that the expression of CD49d increased on TNF- $\alpha$-producing CD4 cells in severe asphyxia, which might further indicate the increased potential of these cells to enter the CNS. Rothhammer et al. were able to demonstrate that under Th1 differentiation promoting circumstances, naive $\mathrm{T}$ cells (CD4+ CD44- FoxP3-) differentiate into encephalitogenic $\mathrm{T}$ cells in approximately 3 days, expressing high amounts of CD49d in mice [75]. It is, therefore, possible that an initial decrease in the prevalence of $\mathrm{CD} 49 \mathrm{~d}+$ lymphocytes due to extravasation is followed by differentiation of CD4+ CD49d+ lymphocytes from the naïve $\mathrm{T}$ lymphocyte pool, leading to an increased prevalence of circulating CD49d+ cells as part of an ongoing inflammatory response. 


\section{Anti-inflammatory factors}

In order to comprehensively assess the immunosuppressive components of the adaptive immune system in neonatal asphyxia, we examined TGF- $\beta$ levels, along with the prevalence of Treg cells and the involvement of the KYN pathway. TGF- $\beta$ plays a critical role in immunosuppression both by inhibiting inflammatory cells and promoting the function of Treg cells via inducing their FoxP3 expression [76-82]. Activated Tregs then produce large amounts of TGF- $\beta$, which acts as an important autocrine signal in their activation [83]. TGF- $\beta$ specifically limits Th1 differentiation and expansion [84, 85] without affecting Th2 effector function and suppresses the production of pro-inflammatory cytokines, while promoting the production of anti-inflammatory IL-10 [86]. Besides direct inhibition, Tregs also inhibit $\mathrm{T}$ cell function by affecting the APC-T cell interactions, for example via the CTLA-4 engagement-induced TRP catabolism by IDO $[87,88]$.

TGF- $\beta$ is associated with the reparation of the infarcted tissue and thus is expressed later than pro-inflammatory cytokines [13]. Interestingly, we observed an elevation after $24 \mathrm{~h}$ in the intracellular level of TGF- $\beta$ in moderate asphyxia that was not present following a severe insult, where the level of TGF- $\beta$ remained comparable to the $6 \mathrm{~h}$ level throughout the whole observation period. We found increased CD49d-expression, which indicates a higher potential of TGF- $\beta$ producing cells to enter the CNS at 1 week and 1 month compared to $72 \mathrm{~h}$ in the moderate group. These findings suggest that TGF- $\beta$ plays an important role in attenuating the inflammatory response and in tissue regeneration following the hypoxic insult in moderate asphyxia. The lack of this effect may contribute to a more severe outcome. We found a moderately elevated prevalence of Tregs in severe compared to moderate asphyxia at $24 \mathrm{~h}$, which might be part of a compensatory mechanism; however, the biological significance of this increase is unremarkable.

Plasma KYN levels were higher at 1 month in the moderate than in the severe group, which might contribute to an immunosuppressive effect. KYN levels showed a decline in both groups by 1 week following the insult (Fig. 4). Similar results were observed for KYNA, while TRP levels increased significantly by 1 month in both groups. In line with the above, the $\mathrm{K} / \mathrm{T}$ ratio, indicating IDO enzymatic activity, plummeted by 1 month in both groups. This increased activation of IDO and TRP catabolism in the postnatal period (up to 1 week) appears to be part of a regulatory mechanism that might play an important role in attenuating the inflammatory response following the hypoxic insult. This effect was comparable in moderate and severe asphyxia, which could mean that this early activation of the KYN pathway is part of the physiological process that accompanies the neuroinflammatory response. However, it appears that the importance of this regulatory mechanism decreases by 1 month.

A limitation of our study is that we did not investigate cell prevalence or cytokine levels in CSF samples. Although this would have provided further data on the local inflammatory response in the CNS, the collection of CSF samples was not possible due to ethical considerations in the lack of clinical indication. A further limitation of this study is the fact that five neonates in each study group (Table 1) received hydrocortisone during intensive care which might have influenced their cytokine balance. Further studies are needed to establish the immunologic effects of hydrocortisone therapy in HIE infants undergoing intensive therapy. Finally, the relatively low number of participants limits the direct clinical utility of the assessment of the prevalence of CD4+ IL- $1 \beta+$ and $\mathrm{CD} 4+\mathrm{IL}-1 \beta+\mathrm{CD} 49 \mathrm{~d}+$ cells at $6 \mathrm{~h}$ as a predictive marker for the severity of the insult at an early stage in asphyxia.

\section{Conclusion}

In conclusion, the need for more specific prognostic markers other than clinical assessment in neonatal asphyxia is clear, since clinical signs often do not correlate with neurological outcome and do not enable differentiation between moderate and severe hypoxic-ischemic encephalopathy. The role of various cytokines in neuroinflammation following hypoxic-ischemic injury is supported by a rapidly expanding body of evidence. IL-1 $\beta$ and IL-6 appear to play a key role in the early events of the inflammatory response, while TNF- $\alpha$ seems to be responsible for triggering a prolonged inflammation, potentially contributing to a worse outcome. On the other hand, TGF- $\beta$ has a compensatory role in decreasing the

Table 3 Summary of the proposed effects of distinct cytokines on the severity of neonatal asphyxia

\begin{tabular}{|c|c|c|}
\hline & Pro-inflammatory & Anti-inflammatory \\
\hline $\begin{array}{l}\text { Contribution to better } \\
\text { outcome }\end{array}$ & $\begin{array}{l}\text { IL-1ß: rapid decrease, higher initial prevalence, and extravasation in } \\
\text { severe insult } \\
\text { G-CSF: rapid decrease in moderate insult, higher plasma levels in } \\
\text { severe insult }\end{array}$ & $\begin{array}{l}\text { TGF- } \beta \text { : increased production and extravasation in } \\
\text { moderate insult } \\
\text { IDO: early compensation up to } 1 \text { week }\end{array}$ \\
\hline $\begin{array}{l}\text { Contribution to worse } \\
\text { outcome }\end{array}$ & $\begin{array}{l}\text { TNF-a: elevated intracellular levels up to } 1 \text { month } \\
\text { IL-17: high prevalence in severe insult up to } 1 \text { month } \\
\text { IL-6: higher plasma levels in severe insult at } 1 \text { week, decrease in } \\
\text { moderate insult by } 1 \text { month }\end{array}$ & $\begin{array}{l}\text { Treg: unremarkable difference at } 24 \mathrm{~h} \text {, not } \\
\text { upregulated }\end{array}$ \\
\hline
\end{tabular}


level of inflammation from an early stage following the insult (Table 3). Based on ROC analysis, the assessment of the prevalence of CD4+ IL- $1 \beta+$ and CD4+ IL- $1 \beta+$ CD $49 d$ + cells at $6 \mathrm{~h}$ appears to be able to predict severity at an early stage in asphyxia (Fig. 5). Our current results open a potentially fruitful area of research as well as diagnostic and therapeutic development in neonatal asphyxia.

\section{Abbreviations}

APC: Antigen presenting cell; BBB: Blood-brain barrier; CD: Cluster of differentiation; CTLA-4: Cytotoxic T-lymphocyte associated protein 4; IDO: Indoleamine 2,3-dioxygenase; IFN- $\gamma$ : Interferon- $\gamma$; IL: Interleukin; KYN: Kynurenine; KYNA: Kynurenic acid; MFI: Mean fluorescence intensity; NMDA: N-methyl-D-aspartate; PBMC: Peripheral blood mononuclear cells; TGF- $\beta$ : Transforming growth factor- $\beta$; Th: Helper T lymphocyte; TNFa: Tumor necrosis factor-a; Treg: Regulatory T Iymphocyte; TRP: Tryptophan VCAM-1: Vascular cell adhesion molecule-1; VLA-4: Very Late Antigen-4

\section{Acknowledgements \\ The authors are grateful to Attila Bajtai and Márton Szentirmai (Department of Neurology, Faculty of Medicine, University of Szeged, Szeged, Hungary) for their valuable assistance during HPLC method development, to Andrea Lakatos (Department of Radiology, Semmelweis University, Budapest, Hungary) for evaluating MR data, and to Beáta Mátrai (Bio-Rad Hungary) for her expert advice during plasma cytokine measurements.}

\section{Funding}

This work was supported by OTKA grant No. 109451 and GINOP grant 2.3.215-2016-00048 STAY ALIVE. DZ and GT are recipients of the Bolyai Scholarship of the Hungarian Academy of Sciences.

\section{Availability of data and materials}

The datasets used and/or analyzed during the current study are available from the corresponding author on reasonable request.

\section{Authors' contributions}

GT was responsible for the study design, funding, and data interpretation, and was a major contributor in writing the manuscript. $A B$ performed the flow cytometry measurements and analyzed the data and was responsible for writing the manuscript. CO and LB performed the flow cytometry measurements. GV and DZ were responsible for developing and performing the HPLC measurements and data analysis. LV interpreted HPLC data. DZ and LV were contributors in writing the manuscript. MS oversaw the clinical care, interpreted the clinical data, and contributed to the writing of the manuscript. ÜM collected and interpreted the aEEG data of the patients. HB collected and interpreted the clinical data and revised the manuscript. Tा made contributions to the study conception and design and revised the manuscript critically. All authors read and approved the final manuscript.

\section{Authors' information}

$V L$ is a professor of Neurology and an expert of the kynurenine system. $\pi T$ is a professor of Pediatrics and an expert of neonatal development. MS is the head of the Neonatal Intensive Care Unit of the First Department of Pediatrics at Semmelweis University, Budapest (regional cooling centre), and an expert on neonatal asphyxia. GT is a consultant neonatologist and an expert of neonatal immunology.

\section{Ethics approval and consent to participate}

Our study was reviewed and approved by the Hungarian Medical Research Council (TUKEB 6578-0/2011-EKU), and written informed consent was obtained from parents of all participants. The study was adhered to the tenets of the most recent revision of the Declaration of Helsinki.

\section{Consent for publication}

Not applicable

\section{Competing interests}

The authors declare that they have no competing interests.

\section{Publisher's Note}

Springer Nature remains neutral with regard to jurisdictional claims in published maps and institutional affiliations.

\section{Author details}

${ }^{1}$ First Department of Obstetrics and Gynecology, Semmelweis University, Baross str. 27, Budapest H-1088, Hungary. ${ }^{2}$ First Department of Pediatrics, Semmelweis University, Bókay János str. 53-54, Budapest H-1083, Hungary. ${ }^{3}$ Department of Neurology, Albert Szent-Györgyi Clinical Centre, Faculty of Medicine, University of Szeged, Semmelweis str. 6, 5th floor, Szeged H-6725, Hungary. ${ }^{4}$ MTA-SZTE Neuroscience Research Group, Szeged, Hungary. ${ }^{5}$ MTA-SE Pediatrics and Nephrology Research Group, Budapest, Hungary. ${ }^{6}$ Birmingham Women's and Children's Hospital, Neonatal Unit, Birmingham, UK.

Received: 29 September 2017 Accepted: 5 December 2017

Published online: 12 December 2017

\section{References}

1. Lawn JE, Cousens S, Zupan J. 4 million neonatal deaths: when? where? why? Lancet. 2005;365(9462):891-900.

2. Beckstrom AC, Humston EM, Snyder LR, Synovec RE, Juul SE. Application of comprehensive two-dimensional gas chromatography with time-of-flight mass spectrometry method to identify potential biomarkers of perinatal asphyxia in a non-human primate model. J Chromatogr A. 2011;1218(14): 1899-906.

3. Okazaki K, Nishida A, Kato M, Kozawa K, Uga N, Kimura H. Elevation of cytokine concentrations in asphyxiated neonates. Biol Neonate. 2006;89(3):183-9.

4. Medana I, Li Z, Flugel A, Tschopp J, Wekerle H, Neumann H. Fas ligand (CD95L) protects neurons against perforin-mediated T lymphocyte cytotoxicity. J Immunol. 2001;167(2):674-81.

5. Giuliani F, Goodyer CG, Antel JP, Yong WW. Vulnerability of human neurons to T cell-mediated cytotoxicity. J Immunol. 2003;171(1):368-79.

6. Schwartz M, Moalem G, Leibowitz-Amit R, Cohen IR. Innate and adaptive immune responses can be beneficial for CNS repair. Trends Neurosci. 1999: 22(7):295-9.

7. Kerschensteiner M, Meinl E, Hohlfeld R. Neuro-immune crosstalk in CNS diseases. Neuroscience. 2009;158(3):1122-32.

8. D'Souza S, Alinauskas K, McCrea E, Goodyer C, Antel JP. Differential susceptibility of human CNS-derived cell populations to TNF-dependent and independent immune-mediated injury. J Neurosci. 1995;15(11):7293-300.

9. Torres C, Aranguez I, Rubio N. Expression of interferon-gamma receptors on murine oligodendrocytes and its regulation by cytokines and mitogens. Immunology. 1995:86(2):250-5.

10. Hisahara S, Shoji S, Okano H, Miura M. ICE/CED-3 family executes oligodendrocyte apoptosis by tumor necrosis factor. J Neurochem. 1997; 69(1):10-20

11. Gehrmann J, Banati RB, Wiessner C, Hossmann KA, Kreutzberg GW. Reactive microglia in cerebral ischaemia: an early mediator of tissue damage? Neuropathol Appl Neurobiol. 1995;21(4):277-89.

12. Stoll $G$, Jander S, Schroeter M. Inflammation and glial responses in ischemic brain lesions. Prog Neurobiol. 1998;56(2):149-71.

13. Saliba E, Henrot A. Inflammatory mediators and neonatal brain damage. Biol Neonate. 2001:79(3-4):224-7.

14. Merrill JE. Tumor necrosis factor alpha, interleukin 1 and related cytokines in brain development: normal and pathological. Dev Neurosci. 1992;14(1):1-10.

15. Woiciechowsky C, Schoning B, Stoltenburg-Didinger G, Stockhammer F, Volk HD. Brain-IL-1 beta triggers astrogliosis through induction of IL-6: inhibition by propranolol and IL-10. Med Sci Monit. 2004;10(9):Br325-30.

16. Aly H, Khashaba MT, El-Ayouty M, El-Sayed O, Hasanein BM. IL-1 beta, IL-6 and TNF-alpha and outcomes of neonatal hypoxic ischemic encephalopathy. Brain and Development. 2006;28(3):178-82.

17. Savman K, Blennow M, Gustafson K, Tarkowski E, Hagberg H. Cytokine response in cerebrospinal fluid after birth asphyxia. Pediatr Res. 1998;43(6):746-51.

18. Alvarez-Diaz A, Hilario E, de Cerio FG, Valls-i-Soler A, Alvarez-Diaz FJ. Hypoxic-ischemic injury in the immature brain-key vascular and cellular players. Neonatology. 2007;92(4):227-35.

19. Azzopardi DV, Strohm B, Edwards AD, Dyet L, Halliday HL, Juszczak E, Kapellou O, Levene M, Marlow N, Porter E, et al. Moderate hypothermia to treat perinatal asphyxial encephalopathy. N Engl J Med. 2009;361(14):1349-58. 
20. Pongor V, Toldi G, Szabo M, Vasarhelyi B. Systemic and immunomodulatory effects of whole body therapeutic hypothermia. Orv Hetil. 2011;152(15):575-80.

21. Roka A, Beko G, Halasz J, Toldi G, Lakatos P, Azzopardi D, Tulassay T, Szabo $M$. Changes in serum cytokine and cortisol levels in normothermic and hypothermic term neonates after perinatal asphyxia. Inflamm Res. 2013; 62(1):81-7.

22. Abbott NJ. Inflammatory mediators and modulation of blood-brain barrier permeability. Cell Mol Neurobiol. 2000;20(2):131-47.

23. de Vries HE, Blom-Roosemalen MC, van Oosten $M$, de Boer AG, van Berkel TJ, Breimer DD, Kuiper J. The influence of cytokines on the integrity of the blood-brain barrier in vitro. J Neuroimmunol. 1996;64(1):37-43.

24. Issekutz TB. Inhibition of in vivo lymphocyte migration to inflammation and homing to lymphoid tissues by the TA-2 monoclonal antibody. A likely role for VLA-4 in vivo. J Immunol. 1991;147(12):4178-84.

25. Baron JL, Madri JA, Ruddle NH, Hashim G, Janeway CA Jr. Surface expression of alpha 4 integrin by CD4 T cells is required for their entry into brain parenchyma. J Exp Med. 1993;177(1):57-68.

26. Yednock TA, Cannon C, Fritz LC, Sanchez-Madrid F, Steinman L, Karin N. Prevention of experimental autoimmune encephalomyelitis by antibodies against alpha 4 beta 1 integrin. Nature. 1992;356(6364):63-6.

27. Polman $\mathrm{CH}, \mathrm{O}^{\prime}$ Connor PW, Havrdova E, Hutchinson M, Kappos L, Miller DH, Phillips JT, Lublin FD, Giovannoni G, Wajgt A, et al. A randomized, placebocontrolled trial of natalizumab for relapsing multiple sclerosis. N Engl J Med. 2006;354(9):899-910.

28. Liesz A, Zhou W, Mracsko E, Karcher S, Bauer H, Schwarting S, Sun L, Bruder D, Stegemann S, Cerwenka A, et al. Inhibition of lymphocyte trafficking shields the brain against deleterious neuroinflammation after stroke. Brain. 2011;134(Pt 3):704-20.

29. Lee SJ, Benveniste EN. Adhesion molecule expression and regulation on cells of the central nervous system. J Neuroimmunol. 1999;98(2):77-88.

30. Stone TW. Kynurenines in the CNS: from endogenous obscurity to therapeutic importance. Prog Neurobiol. 2001;64(2):185-218.

31. Schwarcz R, Pellicciari R. Manipulation of brain kynurenines: glial targets, neuronal effects, and clinical opportunities. J Pharmacol Exp Ther. 2002; 303(1):1-10.

32. Marchi M, Risso F, Viola C, Cavazzani P, Raiteri M. Direct evidence that release-stimulating alpha $7^{*}$ nicotinic cholinergic receptors are localized on human and rat brain glutamatergic axon terminals. J Neurochem. 2002; 80(6):1071-8.

33. Lugo-Huitron R, Blanco-Ayala T, Ugalde-Muniz P, Carrillo-Mora P, PedrazaChaverri J, Silva-Adaya D, Maldonado PD, Torres I, Pinzon E, Ortiz-Islas E, et al. On the antioxidant properties of kynurenic acid: free radical scavenging activity and inhibition of oxidative stress. Neurotoxicol Teratol. 2011;33(5): 538-47.

34. Mandi $Y$, Vecsei L. The kynurenine system and immunoregulation. J Neural Transm (Vienna). 2012;119(2):197-209.

35. Vecsei L, Szalardy L, Fulop F, Toldi J. Kynurenines in the CNS: recent advances and new questions. Nat Rev Drug Discov. 2013;12(1):64-82.

36. Azzopardi D, Brocklehurst P, Edwards D, Halliday H, Levene M, Thoresen M, Whitelaw A. The TOBY Study. Whole body hypothermia for the treatment of perinatal asphyxial encephalopathy: a randomised controlled trial. BMC Pediatr. 2008;8:17.

37. Cseko AJ, Bango M, Lakatos P, Kardasi J, Pusztai L, Szabo M. Accuracy of amplitude-integrated electroencephalography in the prediction of neurodevelopmental outcome in asphyxiated infants receiving hypothermia treatment. Acta Paediatr. 2013;102(7):707-11.

38. Bosmans JM, Neri E, Ratib O, Kahn CE Jr. Structured reporting: a fusion reactor hungry for fuel. Insights Imaging. 2015;6(1):129-32.

39. Marcovici PA, Taylor GA. Journal Club: structured radiology reports are more complete and more effective than unstructured reports. AJR Am J Roentgenol. 2014;203(6):1265-71.

40. Herve C, Beyne P, Jamault H, Delacoux E. Determination of tryptophan and its kynurenine pathway metabolites in human serum by high-performance liquid chromatography with simultaneous ultraviolet and fluorimetric detection. J Chromatogr B Biomed Appl. 1996;675(1):157-61.

41. Satoh T, Nakamura S, Taga T, Matsuda T, Hirano T, Kishimoto T, Kaziro Y. Induction of neuronal differentiation in PC12 cells by B-cell stimulatory factor 2/interleukin 6. Mol Cell Biol. 1988;8(8):3546-9.

42. Hama T, Miyamoto M, Tsukui H, Nishio C, Hatanaka H. Interleukin-6 as a neurotrophic factor for promoting the survival of cultured basal forebrain cholinergic neurons from postnatal rats. Neurosci Lett. 1989;104(3):340-4.
43. Mehler MF, Marmur R, Gross R, Mabie PC, Zang Z, Papavasiliou A, Kessler JA. Cytokines regulate the cellular phenotype of developing neural lineage species. Int J Dev Neurosci. 1995;13(3-4):213-40.

44. Martin-Ancel A, Garcia-Alix A, Pascual-Salcedo D, Cabanas F, Valcarce M, Quero J. Interleukin-6 in the cerebrospinal fluid after perinatal asphyxia is related to early and late neurological manifestations. Pediatrics. 1997;100(5): 789-94.

45. Buck RH, Cordle CT, Thomas DJ, Winship TR, Schaller JP, Dugle JE. Longitudinal study of intracellular T cell cytokine production in infants compared to adults. Clin Exp Immunol. 2002;128(3):490-7.

46. Jason J, Archibald LK, Nwanyanwu OC, Byrd MG, Kazembe PN, Dobbie H, Jarvis WR. Comparison of serum and cell-specific cytokines in humans. Clin Diagn Lab Immunol. 2001;8(6):1097-103.

47. Ren K, Torres R. Role of interleukin-1beta during pain and inflammation. Brain Res Rev. 2009;60(1):57-64.

48. Friedlander RM, Gagliardini V, Hara H, Fink KB, Li W, MacDonald G, Fishman MC, Greenberg AH, Moskowitz MA, Yuan J. Expression of a dominant negative mutant of interleukin-1 beta converting enzyme in transgenic mice prevents neuronal cell death induced by trophic factor withdrawal and ischemic brain injury. J Exp Med. 1997;185(5):933-40.

49. Yamasaki $Y$, Matsuura N, Shozuhara H, Onodera H, Itoyama $Y$, Kogure K. Interleukin-1 as a pathogenetic mediator of ischemic brain damage in rats. Stroke. 1995;26(4):676-80.

50. Buttini $M$, Boddeke $H$. Peripheral lipopolysaccharide stimulation induces interleukin-1 beta messenger RNA in rat brain microglial cells. Neuroscience. 1995;65(2):523-30.

51. Yabuuchi K, Minami M, Katsumata S, Yamazaki A, Satoh M. An in situ hybridization study on interleukin-1 beta mRNA induced by transient forebrain ischemia in the rat brain. Brain Res Mol Brain Res. 1994;26(1-2):135-42.

52. Hagberg H, Gilland E, Bona E, Hanson LA, Hahin-Zoric M, Blennow M, Holst M, McRae A, Soder O. Enhanced expression of interleukin (IL)-1 and IL-6 messenger RNA and bioactive protein after hypoxia-ischemia in neonatal rats. Pediatr Res. 1996;40(4):603-9.

53. Liu F, Ooi VE, Fung MC. Analysis of immunomodulating cytokine mRNAs in the mouse induced by mushroom polysaccharides. Life Sci. 1999;64(12):1005-11.

54. Garcia JH, Liu KF, Relton JK. Interleukin-1 receptor antagonist decreases the number of necrotic neurons in rats with middle cerebral artery occlusion. Am J Pathol. 1995;147(5):1477-86.

55. Dinarello CA. Biologic basis for interleukin-1 in disease. Blood. 1996;87(6): 2095-147.

56. Rao DA, Tracey KJ, Pober JS. IL-1alpha and IL-1beta are endogenous mediators linking cell injury to the adaptive alloimmune response. J Immunol. 2007;179(10):6536-46.

57. Heneka MT, Kummer MP, Stutz A, Delekate A, Schwartz S, Vieira-Saecker A, Griep A, Axt D, Remus A, Tzeng TC, et al. NLRP3 is activated in Alzheimer's disease and contributes to pathology in APP/PS1 mice. Nature. 2013; 493(7434):674-8.

58. Shahzad K, Bock F, Dong W, Wang H, Kopf S, Kohli S, Al-Dabet MM, Ranjan S, Wolter J, Wacker C, et al. Nlrp3-inflammasome activation in non-myeloidderived cells aggravates diabetic nephropathy. Kidney Int. 2015;87(1):74-84.

59. Doitsh G, Galloway NL, Geng X, Yang Z, Monroe KM, Zepeda O, Hunt PW, Hatano H, Sowinski S, Munoz-Arias I, et al. Cell death by pyroptosis drives CD4 T-cell depletion in HIV-1 infection. Nature. 2014:505(7484):509-14.

60. Relton JK, Martin D, Thompson RC, Russell DA. Peripheral administration of Interleukin-1 receptor antagonist inhibits brain damage after focal cerebral ischemia in the rat. Exp Neurol. 1996;138(2):206-13.

61. Silveira RC, Procianoy RS. Interleukin-6 and tumor necrosis factor-alpha levels in plasma and cerebrospinal fluid of term newborn infants with hypoxic-ischemic encephalopathy. J Pediatr. 2003;143(5):625-9.

62. Chiesa C, Pellegrini G, Panero A, De Luca T, Assumma M, Signore F, Pacifico L. Umbilical cord interleukin-6 levels are elevated in term neonates with perinatal asphyxia. Eur J Clin Investig. 2003;33(4):352-8.

63. Langrish CL, Chen Y, Blumenschein WM, Mattson J, Basham B, Sedgwick JD, McClanahan T, Kastelein RA, Cua DJ. IL-23 drives a pathogenic T cell population that induces autoimmune inflammation. J Exp Med. 2005;201(2):233-40.

64. Shichita T, Sugiyama Y, Ooboshi H, Sugimori H, Nakagawa R, Takada I, Iwaki T, Okada Y, lida M, Cua DJ, et al. Pivotal role of cerebral interleukin-17producing gammadeltaT cells in the delayed phase of ischemic brain injury. Nat Med. 2009;15(8):946-50.

65. Yang D, Sun YY, Bhaumik SK, Li Y, Baumann JM, Lin X, Zhang Y, Lin SH, Dunn RS. Blocking lymphocyte trafficking with FTY720 prevents 
inflammation-sensitized hypoxic-ischemic brain injury in newborns. J Neurosci. 2014;34(49):16467-81.

66. Pulera MR, Adams LM, Liu H, Santos DG, Nishimura RN, Yang F, Cole GM, Wasterlain CG. Apoptosis in a neonatal rat model of cerebral hypoxiaischemia. Stroke. 1998;29(12):2622-30.

67. Tarkowski E, Rosengren L, Blomstrand C, Jensen C, Ekholm S, Tarkowski A. Intrathecal expression of proteins regulating apoptosis in acute stroke. Stroke. 1999;30(2):321-7.

68. Szaflarski J, Burtrum D, Silverstein FS. Cerebral hypoxia-ischemia stimulates cytokine gene expression in perinatal rats. Stroke. 1995;26(6): 1093-100.

69. Stroemer RP, Rothwell NJ. Exacerbation of ischemic brain damage by localized striatal injection of interleukin-1 beta in the rat. J Cereb Blood Flow Metab. 1998;18(8):833-9.

70. Loddick SA, Turnbull AV, Rothwell NJ. Cerebral interleukin-6 is neuroprotective during permanent focal cerebral ischemia in the rat. J Cereb Blood Flow Metab. 1998;18(2):176-9.

71. Dihne M, Block F. Focal ischemia induces transient expression of IL-6 in the substantia nigra pars reticulata. Brain Res. 2001;889(1-2):165-73.

72. Oygur N, Sonmez O, Saka O, Yegin O. Predictive value of plasma and cerebrospinal fluid tumour necrosis factor-alpha and interleukin-1 beta concentrations on outcome of full term infants with hypoxic-ischaemic encephalopathy. Arch Dis Child Fetal Neonatal Ed. 1998;79(3):F190-3.

73. Foster-Barber A, Dickens B, Ferriero DM. Human perinatal asphyxia: correlation of neonatal cytokines with MRI and outcome. Dev Neurosci. 2001;23(3):213-8.

74. Shohami E, Bass R, Wallach D, Yamin A, Gallily R. Inhibition of tumor necrosis factor alpha (TNFalpha) activity in rat brain is associated with cerebroprotection after closed head injury. J Cereb Blood Flow Metab. 1996; 16(3):378-84.

75. Rothhammer V, Heink S, Petermann F, Srivastava R, Claussen MC, Hemmer B, Korn T. Th17 lymphocytes traffic to the central nervous system independently of alpha4 integrin expression during EAE. J Exp Med. 2011; 208(12):2465-76.

76. Kehrl JH, Wakefield LM, Roberts AB, Jakowlew S, Alvarez-Mon M, Derynck R, Sporn MB, Fauci AS. Production of transforming growth factor beta by human T lymphocytes and its potential role in the regulation of T cell growth. J Exp Med. 1986;163(5):1037-50,

77. Kulkarni AB, Huh CG, Becker D, Geiser A, Lyght M, Flanders KC, Roberts $A B$, Sporn MB, Ward JM, Karlsson S. Transforming growth factor beta 1 null mutation in mice causes excessive inflammatory response and early death. Proc Natl Acad Sci U S A. 1993;90(2):770-4.

78. Gorelik L, Flavell RA. Abrogation of TGFbeta signaling in T cells leads to spontaneous T cell differentiation and autoimmune disease. Immunity. 2000;12(2):171-81.

79. Laouar Y, Sutterwala FS, Gorelik L, Flavell RA. Transforming growth factorbeta controls Thelper type 1 cell development through regulation of natural killer cell interferon-gamma. Nat Immunol. 2005;6(6):600-7.

80. Lucas PJ, Kim SJ, Melby SJ, Gress RE. Disruption of T cell homeostasis in mice expressing a T cell-specific dominant negative transforming growth factor beta II receptor. J Exp Med. 2000;191(7):1187-96.

81. Yang X, Letterio JJ, Lechleider RJ, Chen L, Hayman R, Gu H, Roberts AB, Deng $C$. Targeted disruption of SMAD3 results in impaired mucosal immunity and diminished T cell responsiveness to TGF-beta. EMBO J. 1999; 18(5):1280-91.

82. Wan YY, Flavell RA. 'Yin-Yang' functions of transforming growth factorbeta and T regulatory cells in immune regulation. Immunol Rev. 2007. 220:199-213.

83. Li MO, Wan YY, Flavell RA. T cell-produced transforming growth factorbeta1 controls $T$ cell tolerance and regulates Th1- and Th17-cell differentiation. Immunity. 2007;26(5):579-91.

84. Gorelik L, Flavell RA. Transforming growth factor-beta in T-cell biology. Nat Rev Immunol. 2002;2(1):46-53.

85. Sad S, Mosmann TR. Single IL-2-secreting precursor CD4 T cell can develop into either Th1 or Th2 cytokine secretion phenotype. J Immunol. 1994; 153(8):3514-22.

86. Kitani A, Fuss I, Nakamura K, Kumaki F, Usui T, Strober W. Transforming growth factor (TGF)-beta1-producing regulatory T cells induce Smadmediated interleukin 10 secretion that facilitates coordinated immunoregulatory activity and amelioration of TGF-beta1-mediated fibrosis. J Exp Med. 2003;198(8):1179-88.
87. Fallarino F, Grohmann U, Hwang KW, Orabona C, Vacca C, Bianchi R, Belladonna ML, Fioretti MC, Alegre ML, Puccetti P. Modulation of tryptophan catabolism by regulatory T cells. Nat Immunol. 2003;4(12):1206-12.

88. Tadokoro CE, Shakhar G, Shen S, Ding Y, Lino AC, Maraver A, Lafaille JJ, Dustin ML. Regulatory $T$ cells inhibit stable contacts between CD4+ T cells and dendritic cells in vivo. J Exp Med. 2006;203(3):505-11.

\section{Submit your next manuscript to BioMed Central and we will help you at every step:}

- We accept pre-submission inquiries

- Our selector tool helps you to find the most relevant journal

- We provide round the clock customer support

- Convenient online submission

- Thorough peer review

- Inclusion in PubMed and all major indexing services

- Maximum visibility for your research

Submit your manuscript at www.biomedcentral.com/submit
Biomed Central 